Michał DZIADKIEWICZ, Marta KADŁUBEK

Czestochowa University of Technology

Faculty of Management

Institute of Logistics and International Management

michaldziadkiewicz@gmail.com

\title{
WASTE MANAGEMENT IN POLISH MUNICIPALITIES - EFFECTS OF THE AMENDMENT TO THE ACT ON MAINTAINING THE CLEANLINESS AND ORDER
}

\begin{abstract}
This article attempts to evaluate the effects of the amendment to the Act on maintaining the cleanliness and order in Polish municipalities based on the reports of local governments of the following three voivodeships: the Lesser Poland (Malopolska), Opole and Silesia, in terms of the implementation of provincial waste management plans for the period 2011-2013. The chosen period of analysis includes the breakthrough between the rules of the Act on maintaining the cleanliness and order in municipalities prior to the amendment and after amending it to a large extent. This allows to assess the influence of the amendment on the attitudes of local governments concerning the problem of waste management and the effects of changing those attitudes according to the letter of the amended law.
\end{abstract}

Keywords: waste management, the Act on maintaining the cleanliness and order in municipalities, municipal waste, waste recovery, recycling

\section{ZARZĄDZANIE GOSPODARKĄ ODPADAMI W POLSKICH GMINACH - EFEKTY NOWELIZACJI USTAWY O UTRZYMANIU CZYSTOŚCI I PORZĄDKU}

Streszczenie. W artykule podjęto próbę oceny efektów nowelizacji ustawy o utrzymaniu czystości i porządku w polskich gminach na podstawie sprawozdania samorządów trzech województw: małopolskiego, opolskiego i śląskiego z realizacji wojewódzkich planów gospodarki odpadami za lata 2011-2013. Wybrany okres analizy obejmuje przełom pomiędzy rządami ustawy o utrzymaniu czystości i porządku w gminach w brzmieniu sprzed nowelizacji i tejże ustawy w dużym zakresie zmienionej. Daje to możliwość oceny wpływu nowelizacji na postawy samorządów w stosunku do problemu zarządzania gospodarką odpadami oraz efektów zmiany tych postaw, zgodnie z literą ustawy znowelizowanej. 
Słowa kluczowe: zarządzanie gospodarką odpadami, ustawa o utrzymaniu czystości i porządku w gminach, odpady komunalne, odzysk, recykling

\section{Introduction}

The amended in 2011 Act on maintaining the cleanliness and order in municipalities ${ }^{1}$ has imposed on Polish local governments a number of new obligations within the scope of the collection and management of waste. The main direction of the changes, outlined by the amended act, was to gear local governments towards the implementation of modern forms of waste management, strategically ${ }^{2}$ considering their widest possible recovery while minimizing the weight of waste that is subject to the simplest disposal operations, which in practice comes down to their safe storage ${ }^{3}$.

The main objective of the project was to give back to the public sector the control over the waste market in order to comply with international regulations (arising from Council Directive 1999/31/EC of 26 April 1999 on the landfill of waste Dz.U. L 182 of 16.7.1999 and the Directive of the European Parliament and of the Council 2008/98/EC of 19 November 2008 on waste and repealing some directives (Dz.U. L 312 of 22.11.2008) regarding waste storage and recovery ${ }^{4}$. In the justification of the proposed amendments it was pointed out that the private sector had not been able to fulfill these obligations for the preceding 9 years of functioning of the amended act. In spite of giving the decision on the management of municipal waste to the public sector, the changes were supposed to be gentle enough to maintain the majority of jobs related to the transportation of waste.

In addition, due to the indicated amendment, the following achievements were to take place as soon as possible:

- reduction in the level of storage of biodegradable waste to a maximum of $75 \%$ of its mass produced in 1995; and then reducing its storage to $50 \%$ by 31 December 2013 , and by 31 December 2020 - to no more than $35 \%$ of the mass of biodegradable waste produced in 1995 ,

\footnotetext{
${ }^{1}$ Dz.U. (i.e. The Journal of Law of the Republic of Poland) of 2011 No. 152, item 897, the Act of 1 July 2011 on amending the Act on maintaining the cleanliness and order in municipalities and some other acts.

${ }^{2}$ Romanowska M.: Planowanie strategiczne w przedsiębiorstwie. PWE, Warsaw 2009.

${ }^{3}$ Guerrero L.A., Maas G., Holland W.: Solid waste management challenges for cities in developing countries. "Waste Management", Vol. 33, Iss. 1, 2013, p. 220-232.

${ }^{4}$ Goleń M.: Opinia w sprawie rządowego projektu ustawy o zmianie ustawy o utrzymaniu czystości i porządku w gminach oraz niektórych innych ustaw. Biuro Analiz Sejmowych, Warsaw 4.01.2011, parliamentary print no. 3670, http://orka.sejm.gov.pl/rexdomk6.nsf/Opdodr?OpenPage\&nr=3670.
} 
- achieving by 31 December 2019 the recovery and recycling over 50\% of paper, metal, plastic and glass contained in the municipal waste and more than $70 \%$ of nonhazardous construction and demolition waste ${ }^{5}$.

The article attempts to assess the effects of the aforementioned amendment based on the reports of regional governments on the implementation of provincial waste management plans for the years 2011-2013. This period includes the breakthrough between the rules of the Act on maintaining the cleanliness and order in municipalities prior to the amendment and after amending it to a large extent. This gives an opportunity to assess the effect of the amendment on the attitudes of local governments ${ }^{6}$ in relation to the problem of waste management and the effects of changing these attitudes according to the letter of the amended law ${ }^{7}$.

The time perspective for municipalities to implement the solutions mentioned in the amendment was set for 18 months, therefore the fundamentally rebuilt waste management scheme ought to function fully from the second half of 2013.

The effects of actions undertaken by municipalities should be reflected in the results of the implementation of the provincial waste management plans for the period from 1 January 2011 to 31 December 2013. The 2013 results should thus present the effects of the semi-annual waste management in municipalities ${ }^{8}$ in conditions specified in the provisions that amend the Act on maintaining the cleanliness and order in municipalities.

The article uses the reports of three voivodeships in southern Poland that lie close to one another - the Lesser Poland Voivodeship, the Silesian Voivodeship and the Opole Voivodeship, considering on the one hand the geographical location which connects them, and on the other hand the differences that occur between them in terms of the population and industrialization.

Only some of the results concerning waste management, included in the reports on the implementation of the regional waste management plans for the period 2011-2013 in the three aforementioned voivodeships of southern Poland were used to illustrate the dynamics of the changes within the field of waste management.

The analyzed results relate to municipal waste that is received, collected and managed in the area of each voivodeship, as well as produced and subjected to recovery operations, including recycling.

\footnotetext{
${ }^{5}$ Ibidem.

${ }^{6}$ Nogalski B., Klimek A.: Administracja publiczna poprzez proces do struktury. Koncepcja instytucji katastru. CeDeWu, Warsaw 2014.

${ }^{7}$ Dz.U. of 2011, No. 152, item 897: op.cit.

${ }^{8}$ Marshall R.E., Farahbakhsh K.: Systems approaches to integrated solid waste management in developing countries. "Waste Management", Vol. 33, Iss. 4, 2013, p. 988-1003.
} 


\section{The obligations of municipalities in relation to waste management}

The source of the obligations of municipalities in relation to waste management is the provisions of the Act of 13 September 1996 on maintaining the cleanliness and order in municipalities ${ }^{9}$. This Act sets out the tasks of local governments and responsibilities of real estate owners regarding the maintenance of cleanliness and order. It also provides that the maintenance of cleanliness and order in municipalities belongs to obligatory and strategic own tasks of a properly managed municipality ${ }^{10}$.

The scope of obligations of municipalities includes the creation of conditions to perform works connected with the maintenance of cleanliness and order within the municipality or ensuring the performance of those works by means of creating the right organizational units ${ }^{11}$.

With regard to the municipal waste, it is obligatory for the municipality to organize the collection of that waste from the owners of properties inhabited by municipal residents, and in case of an appropriate decision of the municipal council, also to collect the municipal waste from the owners of properties that are not inhabited by the residents of the municipality, but where municipal waste is created ${ }^{12}$.

Furthermore, municipalities are obliged to provide the construction, maintenance and operation of their own or shared with other municipalities buildings, in the form of ${ }^{13}$ :

- regional installations for the processing of the municipal waste,

- catchment basins, in cases when the connection of all properties to the sewage system is not possible or involves excessive costs,

- installation of the equipment for the collection, transport and disposal of animal carcasses or their parts,

- public toilets.

The municipality is obliged to cover all real estate owners within its territory with the system of municipal waste management ${ }^{14}$. It is also obligated to supervise the municipal waste

\footnotetext{
${ }^{9}$ Dz.U. of 1996, No. 132 item 622, The Act of 13 September 1996 on maintaining the cleanliness and order in municipalities.

${ }^{10}$ Targiel K.S.: Wielostanowe opcje realne w decyzjach zrównoważonego rozwoju. „Organizacja i Zarządzanie”, No. 4(20), 2012, p. 133-148.

${ }^{11}$ Shmelev S., Powell J.: Ecological-economic modelling for strategic regional waste. "Ecological Economics", Vol. 59, Iss. 1, 2006, p. 115-130.

${ }^{12}$ Wilson D.C.: Development drivers for waste management. "Waste Management \& Research", Vol. 25, Iss. 3, 2007, p. 197-208.

${ }^{13}$ Dz.U. of 2011, No. 152, item 897: op.cit.

${ }^{14}$ Christopher M.: Logistics and Supply Chain Management. Financial Times, London 2016.
} 
management ${ }^{15}$, including the implementation of tasks entrusted to entities that collect the municipal waste from property owners ${ }^{16}$.

Another responsibility of the municipality is to implement selective collection of the municipal waste, including at least such fractions of waste as ${ }^{17}$ :

- paper,

- metal,

- plastics,

- glass and composite packaging,

- biodegradable municipal waste including biodegradable packaging waste.

Municipalities are also bound to create points of selective collection of the municipal waste in such a way as to provide an easy access to every citizen of the municipality, which are to ensure the reception of such municipal waste as: expired drugs and chemicals, waste batteries and accumulators, waste electrical and electronic equipment, furniture and other bulky waste, used tyres, green waste and construction and demolition waste that makes the municipal waste, as well as the municipal waste set out in detail in the implementing rules issued under the authority of laws.

An important task within the strategy of a properly managed ${ }^{18}$ municipality is to ensure the achievement of the right levels of recycling and preparing certain fractions of the municipal waste for re-use, including construction and demolition waste which constitute the municipal waste, as well as gradual reduction of the weight of the biodegradable municipal waste, put into storage ${ }^{19}$. The implementation of these obligations has been spread in time with the perspective of the final achievement of the assumed objectives by the end of 2020 . This is consistent with the objectives of sustainable development, which assume a harmonious relationship between man and nature and the growth of social welfare ${ }^{20}$.

In connection with the general obligation to maintain cleanliness, the tasks of the municipality include preventing the contamination of streets, squares and open spaces especially by means of collecting and getting rid of mud, snow, ice and other impurities from the cleared pavements by property owners as well as the waste stored in special bins placed on pavements.

\footnotetext{
${ }^{15}$ Ryszko A.: Environmental management in the Silesian Voivodship enterprises. "Organizacja i Zarządzanie", No. 3(7), 2009.

${ }^{16}$ Ulfik A., Nowak S.: Determinants of municipal waste management in sustainable development of regions in Poland. "Polish Journal of Environmental Studies", Vol. 23, No. 3, 2014, p. 1039-1044.

${ }^{17}$ Dz.U. of 2011, No. 152, item 897: op.cit.

${ }^{18}$ Stachowicz J., Nowicka-Skowron M., Voronina L.A.: Rozwój organizacji i regionu wyzwaniem dla ekonomii i nauk o zarządzaniu. Dom Organizatora TNOiK, Torun 2014.

${ }^{19}$ Bajdor P., Ulfik A.: Nowak S., The selected aspects of sustainable development in supply chain management (SCM). "Applied Mechanics and Materials", Vol. 708, 2015, p. 3-7.

${ }^{20}$ Nowak S., Ulfik A.: An evaluation of regional development in the context of economic and environmental benefits. "Polish Journal of Management Studies", Vol. 10, No. 1, 2014, p. 74-83.
} 
In addition, municipalities are obliged to carry out a variety of actions of informative and educational nature ${ }^{21}$ within the scope of the proper management of the municipal waste, in particular with regard to the selective collection of the municipal waste.

Obligations of municipalities related to waste management ${ }^{22}$, in the fields covered by the Act of 13 September 1996 on maintaining the cleanliness and order in municipalities, were extended and elaborated on in the amendment to that Act contained in the Act of 1 July 2011 on amending the Act on maintaining the cleanliness and order in municipalities and some other acts, which entered into force from 1 January 2012.

The time perspective for municipalities to implement the solutions mentioned in the amendment was set for 18 months, therefore the fundamentally rebuilt waste management scheme ought to function fully from the second half of 2013.

The Act on maintaining the cleanliness and order in municipalities equips them with the following groups of legal instruments that enable the management of waste:

- legislative instruments enabling the creation of local acts - for instance, resolutions regarding the rules of maintaining the cleanliness and order in the municipality, entrusting the company of the municipality with its own task of maintaining order and cleanliness in its territory, the detailed manner and scope of the provision of services in the field of the collection of municipal waste;

- financial instruments - primarily related to determining the method and rate of fee for the management of municipal waste as well as formal and legal obligations of real estate owners (e.g. concerning the model declaration on the amount of fees);

- repressive instruments - related to financial penalties for the participants of waste management as well as offence and penal legislation for violating the provisions of the law;

- regulatory instruments - connected with the record-keeping of activities regulated in terms of collecting the municipal waste from property owners.

\footnotetext{
${ }^{21}$ Knop L., Olko S.: Ewolucja form organizacyjnych sieci współpracy. „Organizacja i Zarządzanie”, No. 1, 2008, p. 101-116.

${ }^{22}$ Starostka-Patyk M., Kościelniak H.: Evaluation of Waste Management Facilities Performance the Case Study of Activities Comparative Analysis in Poland. Proceedings of the 4th International Conference on Advanced Logistics and Transport (ICALT). Valenciennes, France 2015, p. 114-120.
} 


\section{The amount of the municipal waste received and collected in the period of 2011-2013}

According to the definition contained in Article 3 par 1 point 7 of the Act of 14 December 2012 on waste $^{23}$, the term 'municipal waste' is understood as the waste generated by households, with the exception of end-of-life vehicles, as well as the waste that does not contain hazardous waste coming from other waste producers, which due to its nature or composition is similar to the waste from households; mixed municipal waste remains mixed municipal waste, even if it has been subject to waste treatment operations that have not changed its properties in a significant way.

Received municipal waste is defined as waste that is received from the property, regardless of whether it has been gathered as mixed waste or in a selective way ${ }^{24}$.

On the other hand, the notion of collected municipal waste denotes municipal waste that has been collected in containers in public places or delivered directly to the collection points $^{25}$. The sum of the amount of the received and collected municipal waste gives the overall weight of the municipal waste subject to management ${ }^{26}$.

The level of the mass of the received municipal waste in the presented regions in 20112013 was differentiated, with a clear impact of the population size of the voivodeship.

The weight of the municipal waste received in the three selected voivodeships is presented in Table 1.

Table 1

The amount of the received municipal waste in the Lesser Poland Voivodeship,

Silesian Voivodeship and Opole Voivodeship in 2011-2013

\begin{tabular}{|l|c|c|c|}
\hline & \multicolumn{2}{|c|}{ The weight of the received municipal waste (megagrams) } \\
\hline Voivodeship/years & $\mathbf{2 0 1 1}$ & $\mathbf{2 0 1 2}$ & $\mathbf{2 0 1 3}$ \\
\hline Lesser Poland & 736819,80 & 705275,90 & 752616,10 \\
\hline Silesia & 1497777,77 & 1277645,32 & 1282887,98 \\
\hline Opole & 219922,99 & 234195,56 & 207458,66 \\
\hline
\end{tabular}

Source: Own study based on reports on the implementation of the waste management scheme of the following voivodeships: Lesser Poland, Silesia and Opole in the period of 2011-2013. (Mass unit presented in megagrams $[\mathrm{Mg}], 1 \mathrm{MG}$ corresponds to 1 tonne).

The dynamics of changes within the amount of the received municipal waste based on the data from Tab. 1 is shown in Fig. 1 below.

\footnotetext{
${ }^{23}$ Dz.U. of 2013, item 21, the Act of 14 December 2012 on waste.

${ }^{24}$ Li R.C., Tee T.J.C.: A reverse logistics model for recovery options of e-waste considering the integration of the formal and informal waste sectors. "Procedia-Social and Behavioral Sciences", Vol. 40, 2012, p. 788-816.

${ }^{25}$ Dz.U. of 2013, item 21: op.cit.

${ }^{26}$ The division of the municipal waste into received and collected results from the legally binding methodology of reporting on the implementation of the provincial waste management plans for the period 2011-2013, introduced by the guidelines of the Ministry of the Environment for the compilation of a report on the implementation of the provincial waste management plans for the period 2011-2013, Warsaw, February 2014, https://achiwum.mos.gov.pl/g2/big/2014.../d215a343b1a2148b9cf588c357547bb1.doc, 12.11.2016.
} 


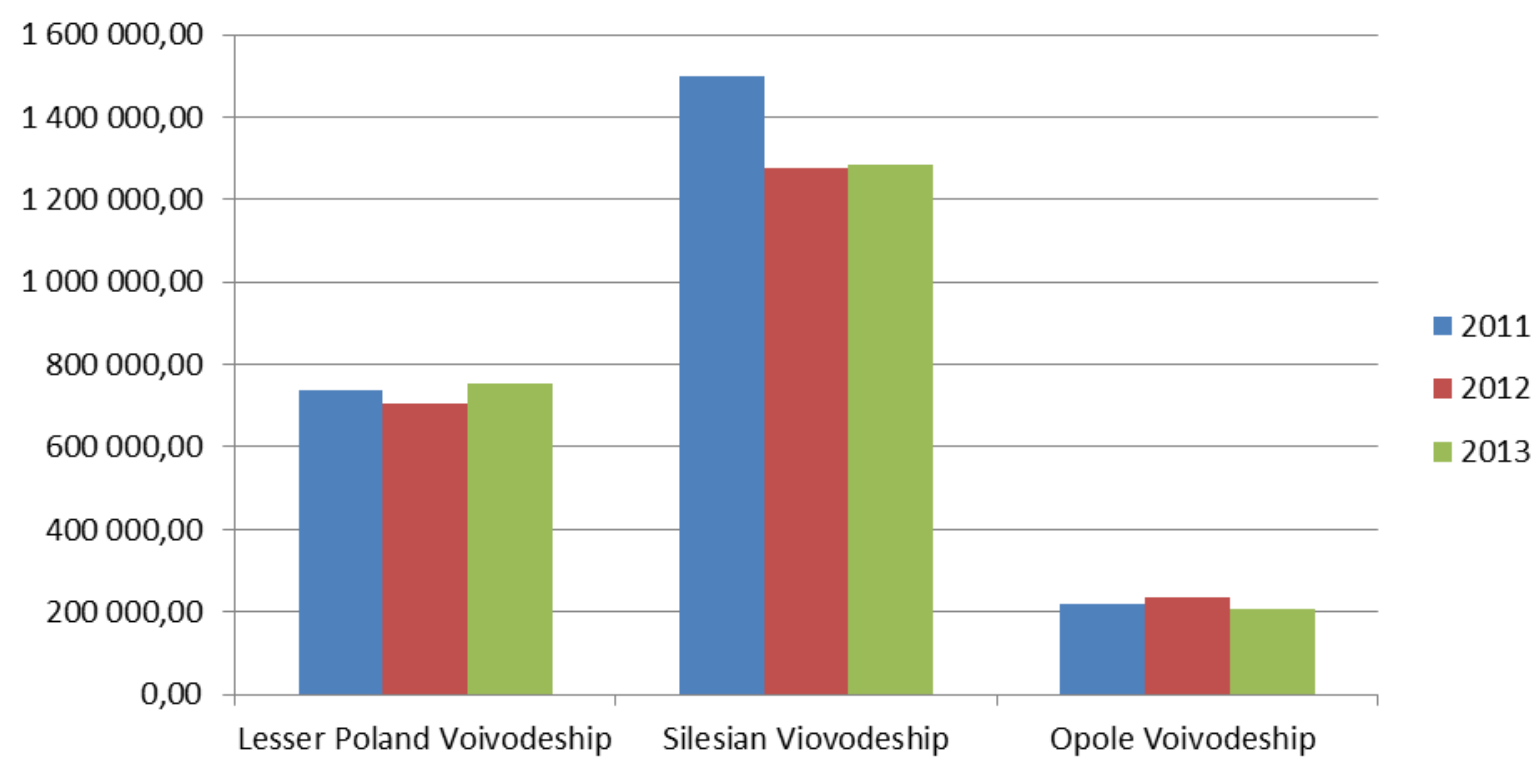

Fig. 1. Dynamics of changes of the amount of the received municipal waste of the Lesser Poland Voivodeship, the Silesian Voivodeship and the Opole Voivodeship in 2011-2013

Source: Own study based on reports on the implementation of the waste management scheme of the following voivodeships: Lesser Poland, Silesia and Opole in the period of 2011-2013. (Mass unit presented in megagrams $[\mathrm{Mg}], 1 \mathrm{MG}$ corresponds to 1 tonne).

The amount of the collected municipal waste for the three chosen voivodeships is presented in Tab. 2 .

Table 2

The amount of the municipal waste collected in the Lesser Poland Voivodeship,

Silesian Voivodeship and Opole Voivodeship in 2011-2013

\begin{tabular}{|l|c|c|c|}
\hline & \multicolumn{3}{|c|}{ The weight of the collected municipal waste (megagrams) } \\
\hline Voivodeship/years & $\mathbf{2 0 1 1}$ & $\mathbf{2 0 1 2}$ & $\mathbf{2 0 1 3}$ \\
\hline Lesser Poland & 0 & 19263,68 & 8090,743 \\
\hline Silesia & 183068,56 & 188820,10 & 107412,16 \\
\hline Opole & 124676,326 & 29,5 & 445,812 \\
\hline
\end{tabular}

Source: Own study based on reports on the implementation of the waste management scheme of the following voivodeships: Lesser Poland, Silesia and Opole in the period of 2011-2013. (Mass unit presented in megagrams $[\mathrm{Mg}], 1 \mathrm{MG}$ corresponds to 1 tonne).

The dynamics of changes in the amount of the collected municipal waste based on the data from Tab. 2 is presented in Fig. 2. 


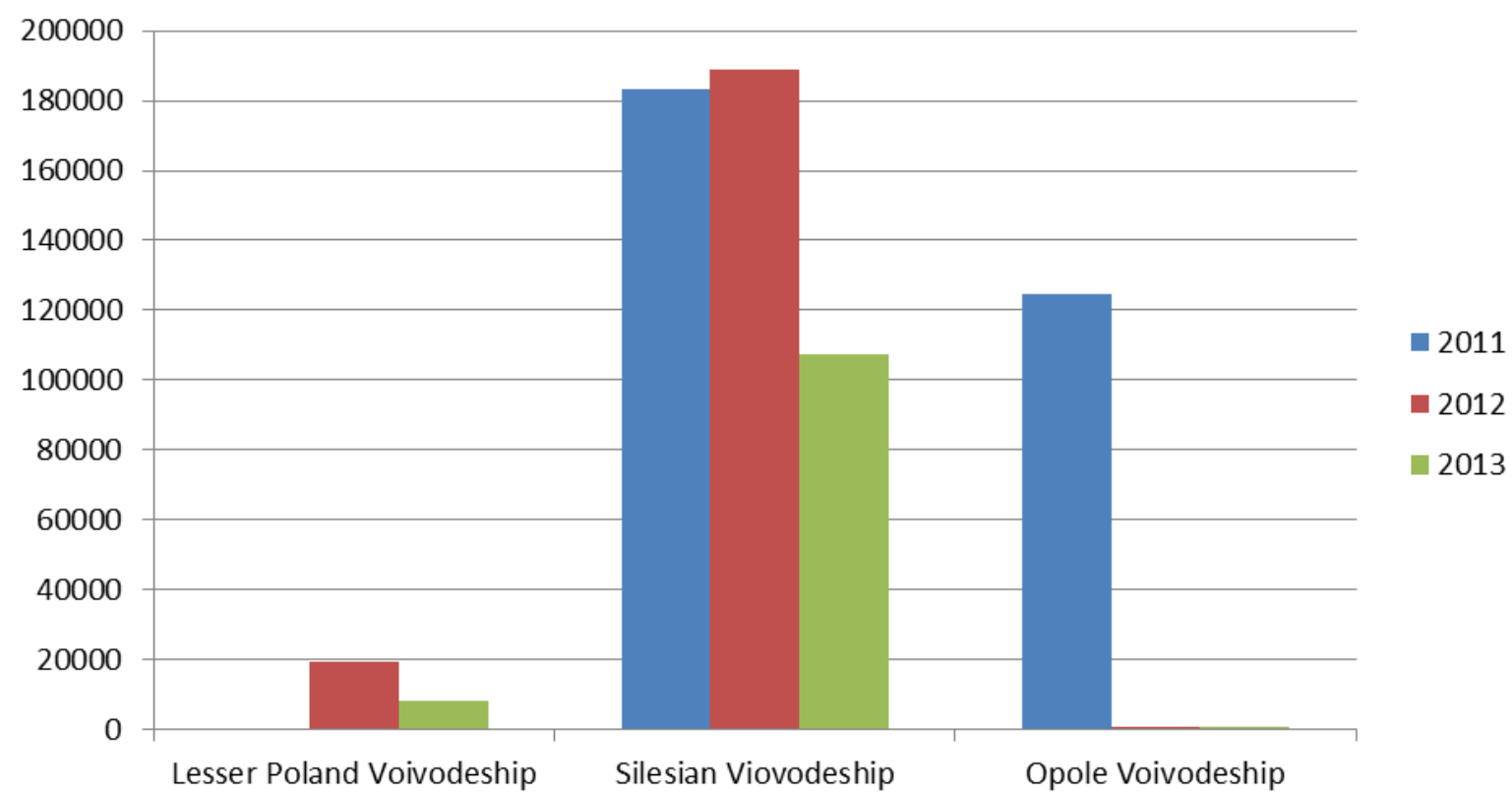

Fig. 2. Dynamics of changes of the amount of the municipal waste collected in the Lesser Poland, Silesian and Opole Voivodeship, in 2011-2013 [Mg] (Mass unit presented in megagrams $[\mathrm{Mg}], 1 \mathrm{MG}$ corresponds to 1 tonne)

Source: Own study based on reports on the implementation of the waste management scheme of the following voivodeships: Lesser Poland, Silesia and Opole in the period of 2011-2013.

\section{Recycling, other recovery and disposal of the municipal waste in 2011-2013}

The level of the management of the municipal waste is determined by the amount of waste subject to recycling or other than recycling recovery processes or even the disposal operation $^{27}$.

Recycling processes ought to be understood as reprocessing of substances or materials contained in waste in the production process in order to obtain substances or material for the original purpose or for other purposes, also including organic recycling ${ }^{28}$. The concept of waste recovery is a wider term and indicates actions involving the use of waste in whole or in part, or leading to the recovery of substances, materials or energies from waste and using them

\footnotetext{
27 Arena U., Gregorio F.D.: A waste management planning based on substance flow analysis. "Resources, Conservation and Recycling", Vol. 85, 2014, p. 54-66.

${ }^{28}$ Mesjasz-Lech A.: Effectiveness of Pro-Environmental Activities Undertaken by Enterprises in Poland. Polish "Journal of Environmental Studies", Vol. 21, Iss. 5A, 2012, p. 303-311.
} 
without creating any threat to life, human health or the environment e.g. using it as fuel or another substance ${ }^{29}$.

The weight of the recycled municipal waste for the three chosen voivodeships is presented in Table 3.

Table 3

Recycling of the municipal waste in the Lesser Poland, Silesian and Opole Voivodeship in 2011-2013

\begin{tabular}{|l|c|c|c|}
\hline & \multicolumn{2}{|c|}{ Recycling of the municipal waste (megagrams) } \\
\hline Voivodeship/years & $\mathbf{2 0 1 1}$ & $\mathbf{2 0 1 2}$ & $\mathbf{2 0 1 3}$ \\
\hline Lesser Poland & 47499,20 & 42107,50 & 46030,00 \\
\hline Silesia & 55779,64 & 56587,631 & 69748,144 \\
\hline Opole & 2789,47 & 3580,41 & 10273,81 \\
\hline
\end{tabular}

Source: Own study based on reports on the implementation of the waste management scheme of the following voivodeships: Lesser Poland, Silesia and Opole in the period of 2011-2013.

The dynamics of changes in relation to the recycling of municipal waste (data from Table 3) is presented in the analyzed regions in Fig. 3.

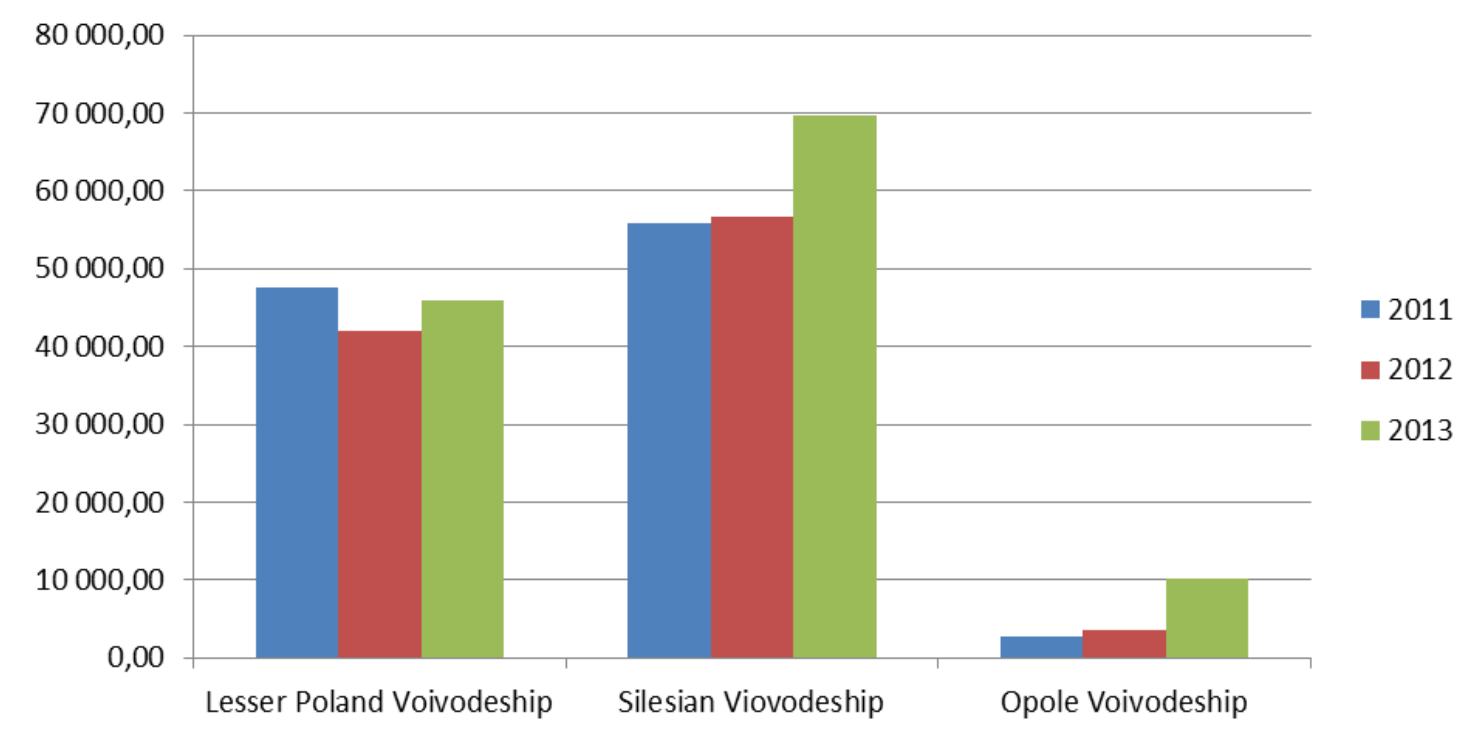

Fig. 3. The level of recycling of the municipal waste in the Lesser Poland Voivodeship, Silesian Voivodeship, and the Opole Voivodeship in 2011-2013

Source: Own study based on reports on the implementation of the waste management scheme of the following voivodeships: Lesser Poland, Silesia and Opole in the period of 2011-2013. (Mass unit presented in megagrams $[\mathrm{Mg}], 1 \mathrm{MG}$ corresponds to 1 tonne).

\footnotetext{
${ }^{29}$ Winter M., Knemeyer A.M.: Exploring the integration of sustainability and supply chain management: current state and opportunities for future inquiry. "International Journal of Physical Distribution \& Logistics Management”, Vol. 43, Iss. 1, 2013, p. 18-38.
} 
In addition to recycling, also other waste recovery operations are used in the process of municipal waste management, and the weight of the municipal waste subjected to these processes as well as the dynamics of changes in the period 2011-2013 have been presented in the analysed voivodeships according to the data in Table 4.

Table 4

Recovery (other than recycling) of the municipal waste in the Lesser Poland Voivodeship, Silesian Voivodeship, and the Opole Voivodeship in 2011-2013

\begin{tabular}{|l|c|c|c|}
\hline & \multicolumn{2}{|c|}{ Recovery (other than recycling) of the municipal waste (megagrams) } \\
\hline Voivodeship/years & $\mathbf{2 0 1 1}$ & $\mathbf{2 0 1 2}$ & $\mathbf{2 0 1 3}$ \\
\hline Lesser Poland & 62290,70 & 409881,60 & 655829,30 \\
\hline Silesia & 962103,37 & 1029372,55 & 1170988,81 \\
\hline Opole & 147347,1 & 131808,16 & 186298,91 \\
\hline
\end{tabular}

Source: Own study based on reports on the implementation of the waste management scheme of the following voivodeships: Lesser Poland, Silesia and Opole in the period of 2011-2013. (Mass unit presented in megagrams $[\mathrm{Mg}], 1 \mathrm{MG}$ corresponds to 1 tonne).

The dynamics of changes in relation to recovery (other than recycling) of the municipal waste (data from Table 4) is presented in the analyzed voivodeships in Fig. 4.

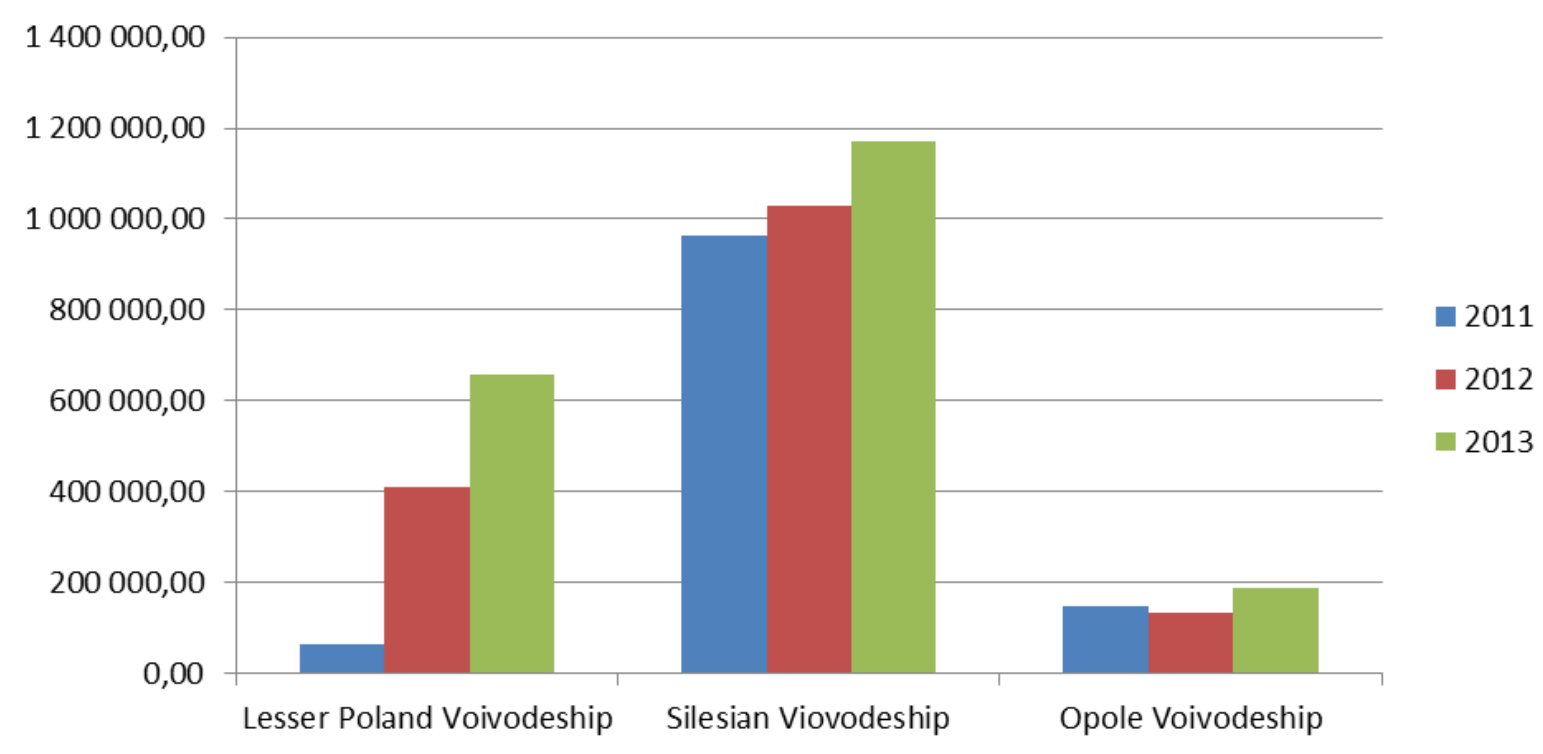

Fig. 4. Dynamics of changes in the amount of recovery (other than recycling) of the municipal waste in 2011-2013, in the Lesser Poland Voivodeship, Silesian Voivodeship, and the Opole Voivodeship

Source: Own study based on reports on the implementation of the waste management scheme of the following voivodeships: Lesser Poland, Silesia and Opole in the period of 2011-2013. (Mass unit presented in megagrams $[\mathrm{Mg}], 1 \mathrm{MG}$ corresponds to 1 tonne).

In addition to the recovery of the municipal waste in both recycling and non-recycling processes, the municipal waste was also subject to the disposal in the analysed period.

The term 'waste disposal' should be understood as subjecting it to processes of biological, physical or chemical transformation in such a way that it does not create any threat to life, 
human health or the environment ${ }^{30}$. The most commonly used method of waste disposal in Poland is storing it, whereas a highly desired and more and more frequently used form of the disposal of waste is its thermal conversion in installations called waste incineration plants.

As a result of the disposal operations of the municipal waste carried out in the Lesser Poland Voivodeship, the Silesian Voivodeship and the Opole Voivodeship in 2011-2013, the amounts presented in Table 5 were obtained.

Table 5

The disposal of the municipal waste in the Lesser Poland Voivodeship,

Silesian Voivodeship, and the Opole Voivodeship in 2011-2013

\begin{tabular}{|l|c|c|c|}
\hline & \multicolumn{3}{|c|}{ Disposal of the municipal waste (megagrams) } \\
\hline Voivodeship/years & $\mathbf{2 0 1 1}$ & $\mathbf{2 0 1 2}$ & $\mathbf{2 0 1 3}$ \\
\hline Lesser Poland & 637707,20 & 264748,60 & 162198,10 \\
\hline Silesia & 369924,08 & 247559,45 & 120513,81 \\
\hline Opole & 117808,3 & 102416,9 & 21605,56 \\
\hline
\end{tabular}

Source: Own study based on reports on the implementation of the waste management scheme of the following voivodeships: Lesser Poland, Silesia and Opole in the period of 2011-2013. (Mass unit presented in megagrams $[\mathrm{Mg}], 1 \mathrm{MG}$ corresponds to 1 tonne).

However, the dynamics of changes of the amount of the municipal waste subject to disposal operations based on the data from Tab. 5, is illustrated by Fig. 5 .

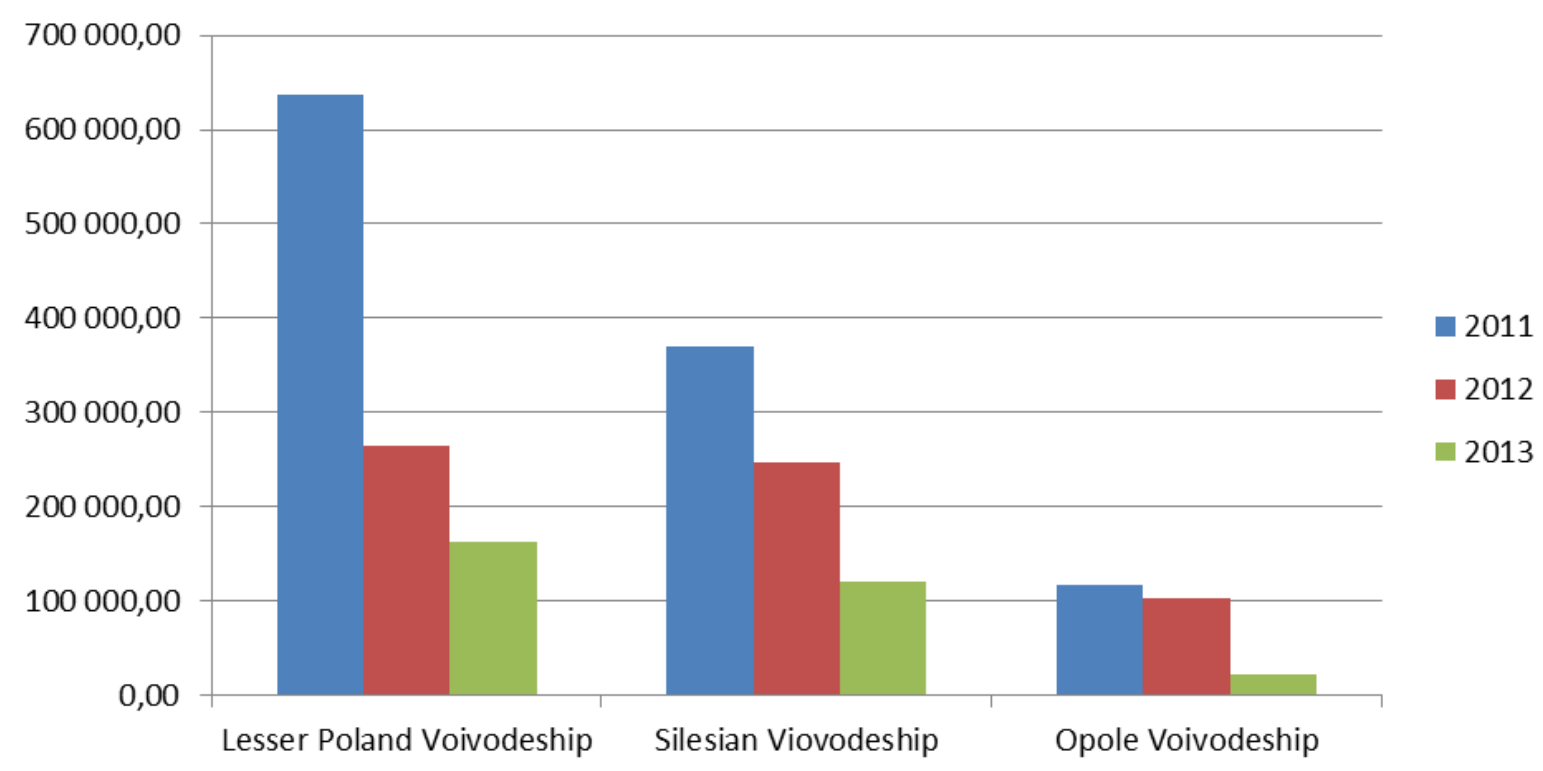

Fig. 5. Dynamics of changes of the amount of the municipal waste subject to disposal operations in 2011-2013, in the Lesser Poland, Silesian and Opole Voivodeships

Source: Own study based on reports on the implementation of the waste management scheme of the following voivodeships: Lesser Poland, Silesia and Opole in the period of 2011-2013. (Mass unit presented in megagrams $[\mathrm{Mg}], 1 \mathrm{MG}$ corresponds to 1 tonne).

\footnotetext{
${ }^{30}$ Dz.U. of 2011, No. 152, item 897: op.cit.
} 


\section{The results of the analysis and conclusions}

An analysis of the data presented in this article should provide an answer to the question whether and in what way the amendment to the Act on maintaining the cleanliness and order in municipalities has affected the implementation of the objective to manage the municipality within this field, that is to increase the amount of the received waste and to manage it in accordance with the provisions of the act on waste and other related acts.

With regard to the municipal waste in the examined municipalities, the following conclusions seem to be the most significant:

a) Municipal waste - the mass to be managed

Results relating to the mass of the municipal waste received and collected in the years 2011-2013 indicate a certain numerical decrease. The generally apparent downward trend is greatly affected by a clear decline in the amount of the collected municipal waste.

The reasons for this decline should be ascribed to the decreasing number of inhabitants, it may also be associated with the results of the financial and economic crisis or even with malpractice within the municipal waste management. However, it should not be excluded that the observed situation may result from consciously taken actions aiming at waste prevention. Stimulating such attitudes is connected with an increase in the fees for the storage of waste, and consequently also with raised charges for receiving the municipal waste from property owners.

b) Recycling of the municipal waste

The level of recycling of the municipal waste in all of the observed voivodeships over the years 2011-2013 increased perceptibly. This general trend is not considerably affected by some reduction in the level of the municipal waste recovery by means of the recycling process observed in the Lesser Poland Voivodeship in the first half of the analysed period.

It may be assumed that this situation is a result of actions performed by municipalities in order to implement the obligations imposed by the Act of 1 July 2011 on amending the Act on maintaining the cleanliness and order in municipalities and some other acts ${ }^{31}$. It ought to be emphasized that according to the Directive 2008/98/EC ${ }^{32}$, which is a key act of the European Union law in the field of waste management, the UE aspires to create the „recycling society”, whose aim would be to ,,avoid generating waste and using waste as resources". 33

c) Recovery of the municipal waste in processes other than recycling

The observed voivodeships show an equally clear upward trend in the recovery of the municipal waste carried out in processes other than recycling, despite the occurrence of

\footnotetext{
${ }^{31}$ Dz.U. of 2011, No. 152, item 897: op.cit.

32 Dz.U. L 312 of 22.11.2008, Directive 2008/98/EC of the European Parliament and of the Council of 19 November 2008 on waste and repealing certain Directives.

${ }^{33}$ The updated national waste management plan of 2014. The project of 17 September 2015, Warsaw 2015.
} 
a slight deflection in using those processes in the first half of the analyzed period in the Opole Voivodeship.

d) Disposal of the municipal waste

The amount of the municipal waste subject to disposal operations is drastically reduced in the analysed period. This trend is by all means correct within the management area, bearing in mind that, as mentioned earlier, the primary method of the disposal of the municipal waste was its storage, whereas the most desirable methods of waste disposal in the form of its incineration (burning) were used on a small scale.

The decreasing amount of the municipal waste subjected to disposal operations in the presence of an increase in the recovery in recycling and non-recycling processes (especially in the second half of the analyzed period), indicates a positive influence of the solutions introduced by the amendment to the Act on maintaining the cleanliness and order in municipalities.

e) Strategic assumptions of the European Union

With regard to the EU Sustainable Development Strategy ${ }^{34}$ and the $7^{\text {th }}$ Environment Action Programme ${ }^{35}$, in which waste prevention and waste management are considered as one of the seven thematic strategies, the relationship between the effective use of resources and waste generation along with waste management is emphasised. The community policy in this field aims to eliminate the relationship between the use of resources, the generation of waste and the economic growth, and at the same time to guarantee that sustainable consumption will not exceed the capacity of the environment. In order to measure the progress in connection with the UE policy on waste in 2010, an assessment of the thematic strategy, including the one on the municipal waste management, was introduced.

Analysis of the data presented herein in relation to the assessment of the EU thematic strategy (as above), allows to conclude that some progress has been made in several areas, including the field of legislative changes, higher rates of recycling and recovery other than recycling, smaller amounts of the waste stored and a reduction in the use of hazardous substances as a result of the disposal of the municipal waste.

Nevertheless, these conclusions should also point out a number of issues which might be improved, including particularly those concerning the negative environmental effects, caused by the expected increase in waste production as well as setting new and more ambitious objectives by the municipalities in terms of prevention and recycling.

\footnotetext{
34 European Commission: A strategy for smart, sustainable and inclusive growth. European Commission, Brussels 2010.

${ }^{35}$ European Union Parliament and the Council: Decision No 1386/2013/EU on a General Union Environment Action Programme to 2020 'Living well, within the limits of our planet'. European Union Parliament and the Council, Brussels 2013.
} 


\section{Ending}

The analysis of the data presented in this article allows to draw a cautious conclusion that the amendment to the Act on maintaining the cleanliness and order in the examined municipalities has resulted in the implementation of modern forms of waste management by them and has contributed to the general increase in the level of the municipal waste management through recovery in both recycling and non-recycling processes. At the same time, there was a loss of the amount of waste subject to disposal operations, which, as mentioned before, in practice mostly adopts the nature of safe storage.

However, it should be stressed that the above conclusion may only be based on the outcome of 2013, whose results may indicate developing trends, however, it cannot yet determine the final effect of the introduction of new statutory solutions.

Yet, according to the provision of art. 39. 1. of the Act of 14 December 2012 on waste ${ }^{36}$, the reports on the implementation of the waste management plans are compiled for three-year periods, full proposals regarding the effect of the amendment to the Act on maintaining the cleanliness and order in municipalities on waste management will be possible to formulate on the basis of the figures contained in the reports on the implementation of the provincial waste management plans for the years 2014-2016.

However, it should be noted that on 18 November 2014 the Sejm adopted further amendments to the law on maintaining order and cleanliness in municipalities (the Act on amending the Act on maintaining the cleanliness and order in municipalities and some other acts, Dz.U. of 17 January 2015 item 87). This amendment introduced 121 amendments to the existing content of the law, and these amendments, according to applicants, are necessary to avoid misinterpretation of the act and to ensure its proper functioning. The assessment of the impact of this amendment on changes within the area of waste management in municipalities goes beyond the scope of this article, yet it may be clearly stated that the implementation of the amended law will impose additional formal and legal burdens on all the interested subjects. It will be interesting to compare subsequent reports on the implementation of the voivodeship waste management plans, which will involve the effects of the aforementioned amendment.

\footnotetext{
${ }^{36}$ Dz.U. of 2013 item 21: op.cit.
} 


\section{Bibliography}

1. Arena U., Gregorio F.D.: A waste management planning based on substance flow analysis. "Resources, Conservation and Recycling", Vol. 85, 2014.

2. Bajdor P., Ulfik A., Nowak S.: The selected aspects of sustainable development in supply chain management (SCM). "Applied Mechanics and Materials”, Vol. 708, 2015.

3. Christopher M.: Logistics and Supply Chain Management. Financial Times, London 2016.

4. Dz.U. (i.e. The Journal of Law of the Republic of Poland) of 1996, No. 132, item 622, The Act of 13 September 1996 on maintaining the cleanliness and order in municipalities.

5. Dz.U. of 2011, No. 152, item 897, The Act of 1 July 2011 on amending the Act on maintaining the cleanliness and order in municipalities and some other acts.

6. Dz.U. of 2013, item 21, the Act of 14 December 2012 on waste.

7. European Commission: A strategy for smart, sustainable and inclusive growth. European Commission, Brussels 2010.

8. European Union Parliament and the Council: Decision No 1386/2013/EU on a General Union Environment Action Programme to 2020 'Living well, within the limits of our planet'. European Union Parliament and the Council, Brussels 2013.

9. Goleń M.: Opinia w sprawie rządowego projektu ustawy o zmianie ustawy o utrzymaniu czystości i porządku w gminach oraz niektórych innych ustaw. Biuro Analiz Sejmowych, Warsaw 4.01.2011, parliamentary print no. 3670, http://orka.sejm.gov.pl/rexdomk6.nsf/ Opdodr?OpenPage\&nr=3670.

10. Guerrero L.A., Maas G., Holland W.: Solid waste management challenges for cities in developing countries. "Waste Management”, Vol. 33, Iss. 1, 2013.

11. https://achiwum.mos.gov.p1/g2/big/2014.../d215a343b1a2148b9cf588c357547bb1.doc.

12. Knop L., Olko S.: Ewolucja form organizacyjnych sieci współpracy. „Organizacja i Zarządzanie", No. 1, 2008.

13. Li R.C., Tee T.J.C.: A reverse logistics model for recovery options of e-waste considering the integration of the formal and informal waste sectors. "Procedia-Social and Behavioral Sciences", Vol. 40, 2012.

14. Marshall R.E., Farahbakhsh K.: Systems approaches to integrated solid waste management in developing countries. "Waste Management", Vol. 33, Iss. 4, 2013.

15. Mesjasz-Lech A.: Effectiveness of Pro-Environmental Activities Undertaken by Enterprises in Poland. "Polish Journal of Environmental Studies", Vol. 21, Iss. 5A, 2012.

16. Nogalski B., Klimek A.: Administracja publiczna poprzez proces do struktury. Koncepcja instytucji katastru. CeDeWu, Warsaw 2014. 
17. Nowak S., Ulfik A.: An evaluation of regional development in the context of economic and environmental benefits. "Polish Journal of Management Studies", Vol. 10, No. 1, 2014.

18. Romanowska M.: Planowanie strategiczne w przedsiębiorstwie. PWE, Warsaw 2009.

19. Ryszko A.: Environmental management in the Silesian Voivodeship enterprises. "Organizacja i Zarządzanie”, No. 3(7), 2009.

20. Shmelev S., Powell J.: Ecological-economic modelling for strategic regional waste. “Ecological Economics", Vol. 59, Iss. 1, 2006.

21. Stachowicz J., Nowicka-Skowron M., Voronina L.A.: Rozwój organizacji i regionu wyzwaniem dla ekonomii i nauk o zarządzaniu. Dom Organizatora TNOiK, Torun 2014.

22. Starostka-Patyk M., Kościelniak H.: Evaluation of Waste Management Facilities Performance the Case Study of Activities Comparative Analysis in Poland. Proceedings of the 4th International Conference on Advanced Logistics and Transport (ICALT). Valenciennes, France 2015.

23. Targiel K.S.: Wielostanowe opcje realne w decyzjach zrównoważonego rozwoju. „Organizacja i Zarządzanie”, No. 4(20), 2012.

24. The Board of the Malopolska Region (i.e. Lesser Poland Voivodeship): Report on the implementation of the waste management plan for the Lesser Poland (Malopolska) Voivodeship for 2011-2013. The Marshall Office of the Malopolska Region, Krakow 2014.

25. The Board of the Opole Voivodeship: Report on the implementation of the waste management plan for the Opole Voivodeship for 2011-2013. The Marshall Office of the Opole Voivodeship, Opole 2014.

26. The Board of the Silesian Voivodeship: Report on the implementation of the waste management plan for the Silesian Voivodeship for 2011-2013. The Marshall Office of the Silesian Voivodeship, Katowice 2014.

27. The updated national waste management plan of 2014. The project of 17 September 2015, Warsaw 2015.

28. Ulfik A., Nowak S.: Determinants of municipal waste management in sustainable development of regions in Poland. "Polish Journal of Environmental Studies", Vol. 23, No. 3, 2014.

29. Wilson D.C.: Development drivers for waste management. "Waste Management \& Research", Vol. 25, Iss. 3, 2007.

30. Winter M., Knemeyer A.M.: Exploring the integration of sustainability and supply chain management: current state and opportunities for future inquiry. "International Journal of Physical Distribution \& Logistics Management”, Vol. 43, Iss. 1, 2013. 